\title{
Aerobic digestion of tannery wastewater in a sequential batch reactor by salt-tolerant bacterial strains
}

\author{
G. Durai · M. Rajasimman $\cdot$ N. Rajamohan
}

Received: 17 March 2011 / Accepted: 4 July 2011 / Published online: 22 July 2011

(C) The Author(s) 2011. This article is published with open access at Springerlink.com

\begin{abstract}
Among the industries generating hyper saline effluents, tanneries are prominent in India. Hyper saline wastewater is difficult to treat by conventional biological treatment methods. Salt-tolerant microbes can adapt to these conditions and degrade the organics in hyper saline wastewater. In this study, the performance of a bench scale aerobic sequencing batch reactor (SBR) was investigated to treat the tannery wastewater by the salt-tolerant bacterial strains namely Pseudomonas aeruginosa, Bacillus flexus, Exiguobacterium homiense and Styphylococcus aureus. The study was carried out under different operating conditions by changing the hydraulic retention time, organic loading rate and initial substrate concentration. From the results it was found that a maximum COD reduction of $90.4 \%$ and colour removal of $78.6 \%$ was attained. From this study it was found that the salt-tolerant microorganisms could improve the reduction efficiency of COD and colour of the tannery wastewater.
\end{abstract}

Keywords Tannery Salt tolerant .

Sequential batch reactor - Organic loading rate

G. Durai · M. Rajasimman ( $)$

Environmental Engineering Laboratory,

Department of Chemical Engineering,

Annamalai University, Annamalainagar

608002, Tamilnadu, India

e-mail: raja_simms@yahoo.com

N. Rajamohan

Department of Chemical Engineering,

Sohar University, Sohar, Sultanate of Oman

\section{Introduction}

Hyper saline effluents are generated by various industrial activities. Leather tanning is a wet process from which a large volume of highly saline liquid waste is continuously generated. Due to the variety of chemicals added at different stages of processing of hides and skins, the wastewater has complex characteristics. The details of wastewater generated from tanneries and their characteristics have already been reported in various literatures (Wiegant et al. 1999; Sreeram and Ramasami 2003; Durai and Rajasimman 2011).

Tannery wastewater, rich in both organic matter and total dissolved solids (TDS), is difficult to treat using conventional biological wastewater treatment processes. Major problems encountered in biological treatment were (1) a limited extent of adaptation, as conventional cultures could not be effectively used to treat saline wastewaters of values higher than 3-5\% (w/v) salt (2) salt adaptations of cultures were easily lost when subjected to salt-free medium (3) changes in ionic strength cell disruptions due to shifts in salt concentration, from 0.5 to $2 \%(\mathrm{w} / \mathrm{v})$, caused significant reductions in system performance (Glass and Silverstein 1999) and (4) rapid changes in salt concentrations created adverse effects more than gradual changes.

To overcome these problems halophilic bacteria are required for the treatment of hyper saline wastewater. The interest in halophilic microorganisms is largely motivated not only by the industrial application of these microbes, notably in the production of enzymes, but also for their use in depollution systems (Anton et al. 1999). It has already been shown that high salinity permits the growth of a complex and diverse halophilic microflora in several types of saline water, such as seawater (Benlloch et al. 1995), 
salterns (Rodriguez-Valera et al. 1999; Hollibaugh et al. 2001) and soda lakes (Litchfield and Gillevet 2002; Sorokin and Kuenen 2005; Ward et al. 2000; Kargi and Dincer 1996; Panswad and Anan 1999). Degradation of synthetic substrates using halophiles has already often been studied (Dincer and Kargi 2001; Schiegl et al. 2004).

Sequencing batch reactor (SBR) is a modification of activated sludge process, which has been successfully used to treat municipal and industrial wastewater (Herzbrun et al. 1985; Franta and Wildere 1997). SBR technology has gained more and more importance in wastewater treatment plants. It is known to be a robust system that stands harsh conditions and often been used in order to treat wastewater. The main advantages are easy operation, low cost, handling hydraulic fluctuation, no need for settling tank and sludge recycling as well as organic load without any significant variation in removal efficiency (Keudel and Dichtl 2000).

Some studies have been conducted on the degradation of complex wastewater using halophiles in SBR (Woolard and Irvine 1994, 1995; Kubo et al. 2001; Moon et al. 2002; Uygur and Kargi 2004; Lefebvre et al. 2004). In this study, the salt-tolerant microorganism used by Senthilkumar et al. (2008) for the treatment of tannery wastewater was used in a SBR. The objective of this study is to treat the tannery wastewater in a SBR by varying the hydraulic retention time, initial substrate concentration and to study the kinetics of the degradation of tannery wastewater.

\section{Materials and methods}

\section{Substrate}

The tannery influent was collected from the Ranipet tannery effluent treatment Co. Ltd., Tamilnadu, India and used as an influent for the bioreactor during the experimental period.
Microorganisms

The salt-tolerant bacteria used in this work are Pseudomonas aeruginosa, Bacillus flexus, Exiguobacterium homiense and Styphylococcus aureus. Frozen cultures of pure, salttolerant bacterial colonies stored in agar slants were inoculated on $5 \mathrm{ml}$ nutrient broth media at aseptic conditions. The inoculated broth was incubated in an orbital shaker (Scigenics, India), at $150 \mathrm{rpm}$ and $37^{\circ} \mathrm{C}$, for $24 \mathrm{~h}$. Wellgrown culture suspensions with uniform concentration were used as sources of inoculum for all the experiments.

\section{Experimental setup}

A laboratory-scale plexiglass reactor, with a total volume of $10 \mathrm{~L}$ was used. The schematic diagram of the experimental set up is shown in Fig. 1. Tubes were inserted into the reactor to ensure the filling and withdrawal of the effluent using peristaltic pump. The reactor was supplied with oxygen by fine bubble air diffuser. The operating conditions in the reactor were maintained at the temperature of $30^{\circ} \mathrm{C}$ and $\mathrm{pH}$ of 7 (Durai et al. 2010). The mixing inside the reactor was achieved with a mechanical stirrer at the speed of $150 \mathrm{rpm}$. Each cycle lasted for $24 \mathrm{~h}$ : filling, $1 \mathrm{~h}$; reaction, $20 \mathrm{~h}$; settling, $2 \mathrm{~h}$; withdrawal, $0.75 \mathrm{~h}$ and idle, $0.25 \mathrm{~h}$. The reactor was inoculated with the salttolerant bacteria obtained from Microbial Type Culture Collection and Gene Bank (MTCC), Chandigarh, India.

The reactor was operated for various initial concentrations of $6,240,4,680,3,220$ and $15,60 \mathrm{mgCOD} / \mathrm{L}$ at different organic loading rate (OLR). The effect of OLR was investigated by varying hydraulic retention time (HRT) while maintaining the concentration of the influent constant. The HRT was varied from 5 to 2 days. Initially an OLR of $2 \mathrm{kgCOD} / \mathrm{m}^{3}$ day was applied for 15 days with a HRT of 5 days. Then the OLR was increased to $2.5 \mathrm{kgCOD} / \mathrm{m}^{3}$ by reducing the HRT from 5 to 4 days on 16th day. After reaching the steady state, the organic loading rate was
Fig. 1 Schematic representation of sequential batch reactor

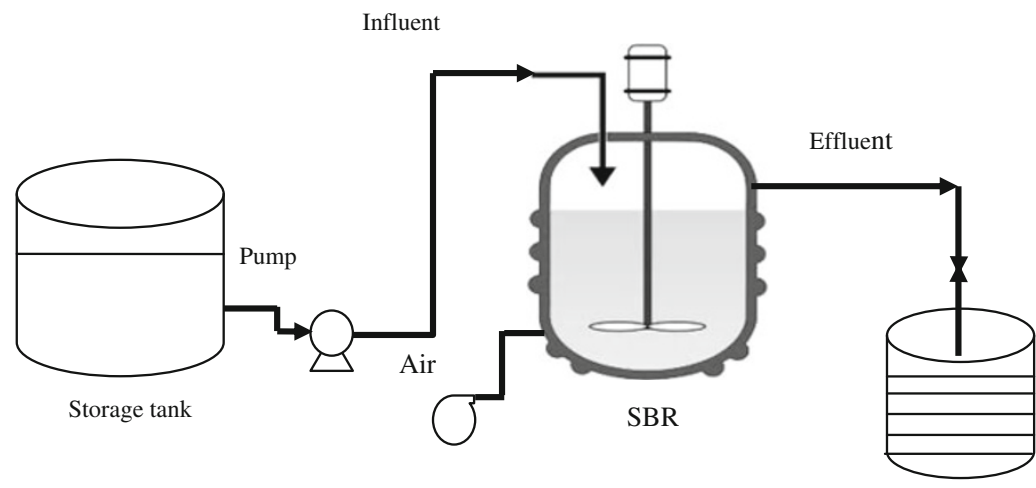

Effluent collection tank 
increased from 2.5 to $3.3 \mathrm{kgCOD} / \mathrm{m}^{3}$ day by reducing the hydraulic retention time to 3 days. Finally the HRT was reduced to 2 days and an OLR of $5 \mathrm{kgCOD} / \mathrm{m}^{3}$ was applied until the end of the experiment. The reactor performance was monitored regularly by measuring effluent COD and colour from the reactor. COD was analysed by APHA's (1992) standard methods for the examination of water and wastewater. Colour reduction was analysed by the method suggested by Bajpai et al. (1993). In this method, sample was centrifuged at $10,000 \mathrm{rev} / \mathrm{min}$ for $30 \mathrm{~min}$ and the $\mathrm{pH}$ was adjusted to 7.6. The absorbance was measured at $465 \mathrm{~nm}$ and transformed into colour units.

\section{Results and discussion}

Tannery wastewater was characterized by the parameters like biochemical oxygen demand (BOD), chemical oxygen demand (COD), suspended solids (SS), Total dissolved solids (TDS), chromium and sulfides etc. Typical characteristics of tannery wastewater were reported in our earlier article (Durai et al. 2010).

\section{COD and colour reduction}

The COD and colour reduction profiles obtained during the degradation of tannery wastewater in a sequential batch reactor are shown in Figs. 2, 3, 4 and 5. The influent and effluent concentrations of the reactor and percentage COD reduction and colour removal for an initial concentration of $6,240 \mathrm{mg} / \mathrm{L}$ are shown in Fig. 2. During the initial stage, the hydraulic retention time (HRT) of the reactor was maintained at 5 days with an organic loading rate of $2 \mathrm{kgCOD} / \mathrm{m}^{3}$ day. In this stage, percentage COD reduction was found to be low due to the fact that microbes need longer time for acclimatization. From the figure, it was observed that a maximum COD reduction of $75.4 \%$ and colour removal of $49.5 \%$ occurs at the fifteenth day from the experiment startup period.

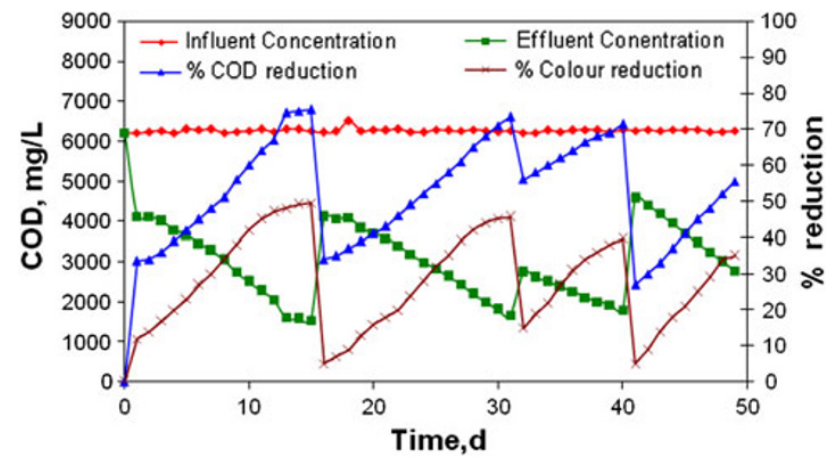

Fig. 2 Effect of HRT on COD reduction at an initial concentration of $6,240 \mathrm{mg} / \mathrm{L}$

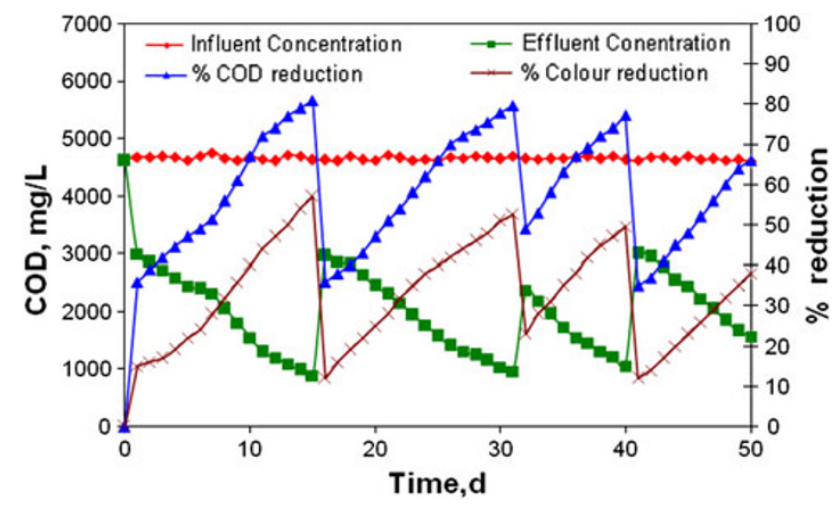

Fig. 3 Effect of HRT on COD reduction at an initial concentration of $4,680 \mathrm{mg} / \mathrm{L}$

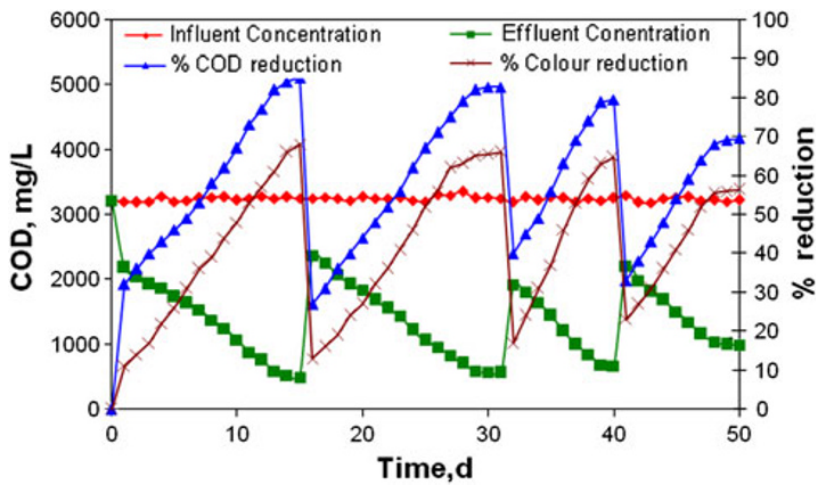

Fig. 4 Effect of HRT on COD reduction at an initial concentration of $3,220 \mathrm{mg} / \mathrm{L}$

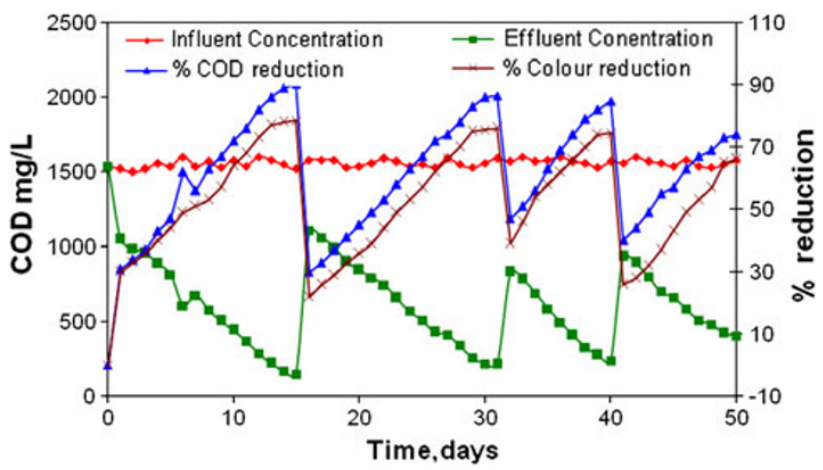

Fig. 5 Effect of HRT on COD reduction at an initial concentration of $1,560 \mathrm{mg} / \mathrm{L}$

The influent COD concentration was maintained at an average concentration of $6,240 \mathrm{mgCOD} / \mathrm{L}$ from the beginning. From Fig. 2, it was also observed that increase in OLR from $2 \mathrm{kgCOD} / \mathrm{m}^{3}$ day to 2.5 leads to a drop in the removal efficiency of COD and colour. The reactor reached steady state within 16 days of operation and the reduction in COD and colour was found to be 73.4 and $45 \%$. 
After reaching the steady state, the organic loading rate was increased from 2.5 to $3.3 \mathrm{kgCOD} / \mathrm{m}^{3}$ day. After 9 days of operation the maximum percentage COD reduction and colour removal were found to be 71.4 and $39.6 \%$, respectively. Then the organic loading rate was increased to $5 \mathrm{kgCOD} / \mathrm{m}^{3}$ day. At this stage, the maximum removal of COD and colour were 56 and $35.4 \%$, respectively. Although there was an instantaneous increase in the OLR while decreasing the HRT, a low effluent COD level was recovered in a short period of time. This shows that SBR has an excellent ability to overcome sudden disturbance in input organic loading.

With decrease in HRT, the percentage COD reduction was also found to decrease. However, a significant drop in percentage COD and colour reduction occurs for the HRT between 3 and 2 days. It was also seen that there was no significant improvement in the degradation of organic matter and colour beyond 3 days. Same trend was observed for the influent concentration of 4,680, 3,220 and 1,560 $\mathrm{mgCOD} / \mathrm{L}$. This is clearly depicted in Figs. 3, 4 and 5. The maximum COD and colour removal at each stage are reported in Table 1.

Figure 6 shows the relationship between the organic loading rate and the COD removal efficiency for overall performance of the reactor. During the initial stages, at low organic loading rate, the COD removal efficiency was found to be high (over 90\%). In the Figure, for the same organic loading rate, a difference in percentage COD reduction was observed and it was due to the fact that the reactor was operated at different initial substrate concentrations.

Kinetics-first order model

The first order model was given by

$-\frac{\mathrm{d} C \mathrm{~s}}{\mathrm{~d} t}=k_{1} C_{\mathrm{s}}$

On integration between known limits, the model can be written as $\ln \left(\frac{C_{\mathrm{s}}}{C_{\mathrm{so}}}\right)=-k_{1} t$

where $C_{\text {so }}$ is the initial substrate concentration (mg COD/ $\mathrm{L}), C_{\mathrm{s}}$ is the substrate concentration $(\mathrm{mg} \mathrm{COD} / \mathrm{L}), t$ is the degradation time $(\mathrm{h})$, and $k_{1}$ is the first order rate constant $\left(\mathrm{h}^{-1}\right)$

The experimental data were fitted to first order model and it is shown in Figs. 7 and 8 (for HRT 5 and 4 days). The figures for HRT 3 and 2 days were not given. The first order rate constant, $k_{1}$, was calculated from the slope of the

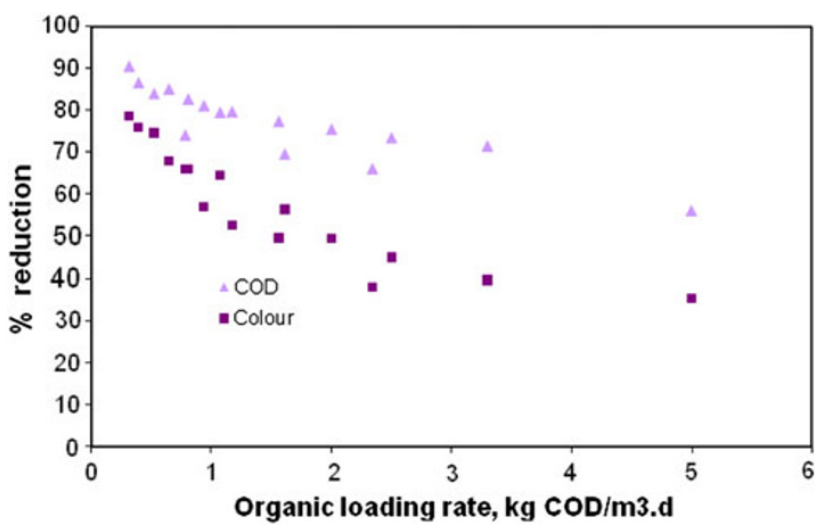

Fig. 6 Effect of OLR on COD reduction and colour removal

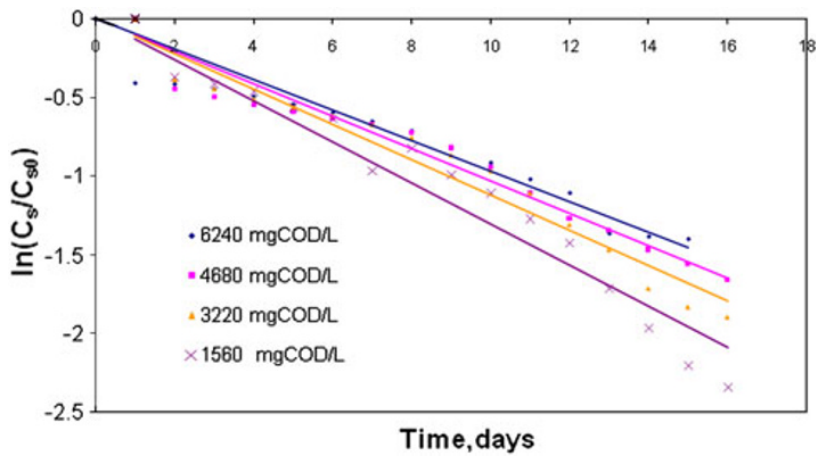

Fig. 7 Comparison of first order model with experimental data at HRT -5 days

Table 1 Removal efficiency of COD and colour at various conditions in a SBR

\begin{tabular}{|c|c|c|c|c|c|c|c|c|}
\hline \multirow[t]{3}{*}{ HRT (days) } & \multicolumn{8}{|c|}{ SBR performance with salt-tolerant micro-organisms } \\
\hline & \multicolumn{4}{|c|}{$\%$ COD reduction } & \multicolumn{4}{|c|}{$\%$ Colour removal } \\
\hline & $6,240 \mathrm{mg} / \mathrm{L}$ & $4,680 \mathrm{mg} / \mathrm{L}$ & $3,220 \mathrm{mg} / \mathrm{L}$ & $1,560 \mathrm{mg} / \mathrm{L}$ & $6,240 \mathrm{mg} / \mathrm{L}$ & $4,680 \mathrm{mg} / \mathrm{L}$ & $3,220 \mathrm{mg} / \mathrm{L}$ & $1,560 \mathrm{mg} / \mathrm{L}$ \\
\hline 5 & 75.4 & 81.0 & 85.0 & 90.4 & 49.5 & 57.0 & 68.0 & 78.6 \\
\hline 4 & 73.4 & 79.6 & 82.6 & 86.5 & 45.0 & 52.6 & 66.0 & 76.0 \\
\hline 3 & 71.4 & 77.3 & 79.4 & 83.9 & 39.6 & 49.6 & 64.6 & 74.6 \\
\hline 2 & 56.0 & 66.0 & 69.5 & 74.0 & 35.4 & 38.0 & 56.4 & 66.0 \\
\hline
\end{tabular}




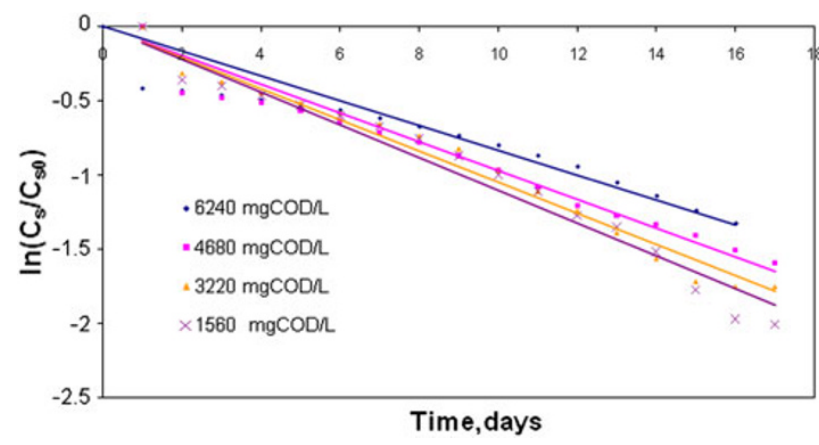

Fig. 8 Comparison of first order model with experimental data at HRT - 4 days

Table 2 Kinetic values and fitness of first order model for the degradation of tannery wastewater in a SBR

\begin{tabular}{llllll}
\hline $\begin{array}{l}\text { First order } \\
\text { model }\end{array}$ & $\begin{array}{l}\text { HRT } \\
\text { (days) }\end{array}$ & \multicolumn{4}{c}{ Initial substrate concentration $(\mathrm{mgCOD} / \mathrm{L})$} \\
\cline { 3 - 6 } & & 1,560 & 3,220 & 4,680 & 6,240 \\
\hline$k_{1}\left(\mathrm{~h}^{-1}\right)$ & 5 & 0.0609 & 0.0534 & 0.0612 & 0.0830 \\
& 4 & 0.0754 & 0.1000 & 0.0811 & 0.0962 \\
& 3 & 0.0972 & 0.1472 & 0.1068 & 0.1155 \\
& 2 & 0.0980 & 0.1643 & 0.1144 & 0.1429 \\
$R^{2}$ & 5 & 0.9920 & 0.9962 & 0.9582 & 0.9504 \\
& 4 & 0.9877 & 0.9953 & 0.9882 & 0.9572 \\
& 3 & 0.9814 & 0.9832 & 0.9766 & 0.9577 \\
& 2 & 0.9937 & 0.9901 & 0.9637 & 0.9569 \\
\hline
\end{tabular}

straight line by the least square (LSQ) fit in the figures. The detailed results including the determination coefficient $\left(R^{2}\right)$ are presented in Table 2. As the initial concentration of substrate increases, the rate constant $k_{1}$ decreases and this can be described to a growing importance of the recalcitrant fraction in reducing the diffusivity of the biodegradable substance. The satisfactory values of $R^{2}$ compliment the ability of the first order model in describing the kinetics of the present work.

\section{Conclusions}

The continuous degradation of tannery wastewater was carried out in a sequential batch reactor using the salttolerant bacteria. The parameters initial substrate concentration and hydraulic retention time are varied. The performance of the system proved that the reduction in COD (90.4\%) and colour (78.6\%) was high. From the results it was found that with decrease in HRT, the percentage COD and colour reduction is found to decrease. However, a significant drop in percentage COD and colour reduction occurs for the HRT between 3 and 2 days. It is also seen that there is no significant improvement in the degradation of organic matter above 3 days. This study proved the feasibility of treating hypersaline tannery wastewater using halophilic bacteria in order to remove the organic matter and colour from the effluent. The capability of the model, namely the first order, representing the continuous kinetic data of the present work was reported. The results indicate that the first order is best suited to describe the aerobic digestion of the tannery wastewater in a sequential batch reactor.

Acknowledgments The authors acknowledge the research grant provided by the Ministry of Environment and Forest, Government of India. The authors wish to express their gratitude for the support extended by the authorities of Annamalai University, Annamalainagar, India in carrying out the research work in Environmental Engineering laboratory, Department of Chemical Engineering.

Open Access This article is distributed under the terms of the Creative Commons Attribution License which permits any use, distribution and reproduction in any medium, provided the original author(s) and source are credited.

\section{References}

Anton J, Llobet-Brossa E, Rodriguez-Valera F, Amann R (1999) Fluorescence in situ hybridization analysis of the prokaryotic community inhabiting crystallizer ponds. Environ Microbiol $1: 517-523$

APHA (1992) Standard methods for the examination of water and wastewater, 16th edn. American Public Health Association, New York

Bajpai P, Mehna A, Bajpai PK (1993) Decolorization of kraft bleach plant effluent with the white rot fungus Trametes versicolor. Process Biochem 28:377-384

Benlloch S, Martinez-Murcia AJ, Rodriguez-Valera F (1995) Sequencing of bacterial and archaeal 16S rRNA genes directly amplified from a hypersaline environment. Syst Appl Microbiol 18:574-581

Dincer AR, Kargi F (2001) Performance of rotating biological disc system treating saline wastewater. Process Biochem 36:901-906

Durai G, Rajasimman M (2011) Biological treatment of tannery wastewater-a review. J Environ sci Technol 4:1-17

Durai G, Rajamohan N, Karthikeyan C, Rajasimman M (2010) Kinetics studies on biological treatment of tannery wastewater using mixed Culture. Int J Chem Biol Eng 3:105-109

Franta JR, Wildere PA (1997) Biological treatment of paper mil wastewater by sequencing batch reactor technology to reduce residual organic. Water Sci Technol 35:129-133

Glass C, Silverstein J (1999) Denitrification of high-nitrate, highsalinity wastewater. Water Res 33:223-229

Herzbrun PA, Irvine RL, Malinowski KC (1985) Biological treatment of hazardous waste in sequencing batch reactors. J Water Pollut Control Fed 57:1163-1167

Hollibaugh JT, Wong PS, Bano N, Pak SK, Prager EM, Orrego C (2001) Stratification of microbial assemblages in Mono Lake, California and response to a mixing event. Hydrobiologia 466:45-60

Kargi F, Dincer AR (1996) Biological treatment of saline wastewater in an aerated percolator unit utilizing halophilic bacteria. Environ Technol 17:325-330

Keudel LO, Dichtl NJ (2000) Settling characteristics of activated sludge in sequencing batch reactors obtained from full-scale 
experiments. In: 2nd International symposium on Sequencing Batch Reactor Technology, Narbone, 10-12 July 2000, pp 75-83

Kubo M, Hiroe J, Murakami M, Fukami H, Tachiki T (2001) Treatment of hypersaline-containing wastewater with salt-tolerant micro-organisms. J Biosci Bioeng 91:222-224

Lefebvre O, Habouzit F, Bru V, Delgenes JP, Godon JJ, Moletta R (2004) Treatment of hypersaline industrial wastewater by a microbial consortium in a sequencing batch reactor. Environ Technol 25:543-553

Litchfield CD, Gillevet PM (2002) Microbial diversity and complexity in hypersaline environments: a preliminary assessment. J Ind Microbiol Biotechnol 28:48-55

Moon BH, Seo GT, Lee TS, Kim SS, Yoon CH (2002) Effects of salt concentration on floc characteristics and pollutants removal efficiencies in treatment of seafood wastewater by SBR. Water Sci Technol 47:65-70

Panswad T, Anan C (1999) Impact of high chloride wastewater on an anaerobic/anoxic/aerobic process with and without inoculation of chloride acclimated seeds. Water Res 33:1165-1172

Rodriguez-Valera F, Acinas SG, Anton J (1999) Contribution of molecular techniques to the study of microbial diversity in hypersaline environments. In: Oren A (ed) Microbiology and biogeochemistry of hypersaline environments. CRC press, Boca Raton, pp 27-38

Schiegl C, Helmreich B, Frnta J, Flemming C, Wildere PA (2004) Residual COD elimination of lignin from paper mil effluent.
Poster presented at IAWQ-Conferences in Singapore. Iran J Environ Health Sci Eng 1:65-69

Senthilkumar S, Surianarayanan M, Sudharshan S, Susheela R (2008) Biological treatment of tannery wastewater by using salt-tolerant bacterial strains. Microb Cell Fact 7:15

Sorokin DY, Kuenen JG (2005) Haloalkaliphilic sulfur-oxidizing bacteria in soda lakes. FEMS Microbiol Rev 29:685-702

Sreeram KJ, Ramasami T (2003) Sustaining tanning process through conservation, recovery and better utilization of chromium. Resour Conserv Recycl 38:185-212

Uygur A, Kargi F (2004) Salt inhibition on biological nutrient removal from saline wastewater in a sequencing batch reactor. Enzyme Microb Technol 34:313-318

Ward BB, Martino DP, Diaz MC, Joye SB (2000) Analysis of ammonia-oxidizing bacteria from hypersaline Mono Lake, California, on the basis of 16S rRNA sequences. Appl Environ Microbiol 66:2873-2881

Wiegant WM, Kalker TJJ, Sontakke VN, Zwaag RR (1999) Full scale experience with tannery water management: an integrated approach. Water Sci Technol 39:169-176

Woolard R, Irvine R (1994) Biological treatment of hypersaline wastewater by a biofilm of halophilic bacteria. Water Environ Res 66:230-235

Woolard R, Irvine R (1995) Treatment of hypersaline wastewater in the sequencing batch reactor. Water Res 29:1159-1168 